\title{
The emergence of the knowledge spillover theory of entrepreneurship
}

\author{
Niccolò Ghio • Massimiliano Guerini $\cdot$ Erik E. Lehmann • Cristina Rossi-Lamastra
}

\begin{abstract}
In the past decade, a new and promising literature has been established linking endogenous growth theory to knowledge spillovers and entrepreneurship theory: the knowledge spillover theory of entrepreneurship (KSTE). This study conducts a bibliometric analysis of scholarly research on this fruitful and promising strand of the literature. It highlights the increasing importance and acceptance of KSTE in the scientific community worldwide, its emergence across different fields in economics, management and policy
\end{abstract}

\section{N. Ghio $(\bowtie) \cdot$ C. Rossi-Lamastra}

Department of Management, Economics and Industrial

Engineering, Politecnico di Milano, Via Lambruschini,

4/C, 20127 Milan, Italy

e-mail: niccolo.ghio@polimi.it

C. Rossi-Lamastra

e-mail: cristina1.rossi@polimi.it

\section{Guerini}

DESTEC, University of Pisa, Largo Lucio Lazzarino, 56122 Pisa, Italy

e-mail: massimiliano.guerini@polimi.it

\section{E. E. Lehmann}

School of Business and Economics, Augsburg University, Universitätsstr. 16, 86159 Augsburg, Germany

e-mail: erik.lehmann@wiwi.uni-augsburg.de

E. E. Lehmann

CCSE, Bergamo, Italy

E. E. Lehmann

CCSE, Augsburg, Germany and also the issues and questions raised. Based on all articles on KSTE published in refereed journals in the past 15 years (1999-2013), we identify the key academic journals, the main issues and subjects addressed and the backward and forward citations. We also identify the authors and their connections in terms of coauthorships to reconstruct the scientific community debating on KSTE. We are confident that our work will benefit scholars intending to leverage KSTE in their research in that it summarizes the main academic conversations within this theoretical perspective and set the boundaries of the network of scholars developing it.

Keywords Knowledge spillover theory of entrepreneurship · Knowledge spillovers · Entrepreneurship $\cdot$ Bibliometric analysis

\section{Introduction}

In the last two decades, a new and promising research field has been initiated linking endogenous growth theory to knowledge spillovers and entrepreneurship theory: the knowledge spillover theory of entrepreneurship (hereafter: KSTE, Acs et al. 2013; Hayter 2013). With his famous book "Innovation and Industry Evolution" in 1995, Audretsch started a fruitful and promising discussion about the importance of small and entrepreneurial firms in creating innovations and fostering growth and wealth. Nowadays, this discussion has been established as an independent field of 
academic research, namely the KSTE, involving scholars from different fields and countries. Audretsch argued that economic growth and technological progresses are by far not only based on the efforts of large and incumbent firms, as proposed by policy makers and the academic mainstream at that time, but are also due to SMEs and entrepreneurial ventures. This provoking hypothesis has been tested empirically in several studies, in particular by Acs and Audretsch (1987, 1988). Moving from these premises, Acs and Audretsch tried to explain the underlying logic of why and how entrepreneurial ventures, in particular in the knowledge-based sectors, increased so rapidly and at least totally changed the industrial structure and dynamics. They argue that the creation of a new venture is a response to opportunities stemming from knowledge generated and not commercially exploited by incumbents firms or academic research institutions (Acs et al. 2013). While incumbent firms are often unable or unwilling to recognize the potential value of these opportunities (e.g., they are unwilling to implement new products or processes that are not consistent with their core competencies and technological trajectories), this knowledge spills over from its source and is leveraged by prospective entrepreneurs to create a new venture. These thoughts, i.e., the view of entrepreneurship as the channel to commercialize knowledge spillovers outside the source of knowledge creation, complement a long lasting scholarly tradition having recognized the role of knowledge as the primary source of technological and commercial opportunities and ultimately of economic growth (e.g., Arrow 1962a, b; Romer 1990; Aghion and Howitt 1992 among others).

In a recent contribution, Acs et al. (2013) position the KSTE against the background of received knowledge by stressing in what it differs from other theories and research streams in the field of entrepreneurship, in particular from endogenous growth theories (Lucas 1988; Romer 1990) as well as from the traditional theoretical approach on entrepreneurship that has been focused on the role of opportunities (Shane 2000, Shane and Venkataraman 2000). They claim that "what distinguishes (KSTE) from other theories of entrepreneurship is that the source of the entrepreneurial opportunities involves knowledge spillovers."

However, to create a bona fide field of the KSTE, some conditions had to be met at least. First, there has to be a genuine and broad interest in the fundamental questions addressed by the KSTE. Second, there has to be sufficient commitment and support to pursue the research agenda posed by those questions. Finally, in our understanding, if the theory takes the form of general laws, they must be testable by empirical studies and show the logical links between specific phenomena and these (economic) laws.

The evolution research on KSTE seems to suggest that these three conditions have been met. Research on KSTE experiences indeed both a focusing and a deepening of the research agenda addresses a welldefined set of questions and has a great focus on the dynamics of growth and wealth of regions and societies. The distinctive questions of the field became "What is the role of knowledge spillovers on entrepreneurship?" "Where do these knowledge spillovers come from?" and "What is the impact of knowledgebased entrepreneurship on society?" The KSTE provides answers to these questions by adopting a broad perspective of the channels through which knowledge spillovers occur and increase economic growth and thus societal wealth. Nevertheless, due to its novelty, KSTE lacks a uniform and formalized definition, while its boundaries are still blurring. This calls for a systematization of the theory, which takes stock of the knowledge developed so far, as Qian and Acs (2013, p. 189) state: "there are ambiguities and missing points in the current form of the KSTE."

In this paper, we heed this call by providing a rigorous bibliometric analysis, which shows how the KSTE has been emerged in the last two decades and how this research is dispersed in the scientific community. Specifically, we map the community of scholars debating on the KSTE, disentangle the main themes addressed by this community and identify the journals mainly hosting the KSTE debate. Through the analysis of backward and forward citations (see Raasch et al. 2013 for a similar approach), we determine the main conceptual pillars on which the KSTE is grounded and the impact of KSTE on other research areas.

The paper adds to previous work on the new and promising field of KSTE by highlighting that the aforementioned three conditions for KSTE to be considered a bona fide field have been met. ${ }^{1}$

\footnotetext{
${ }^{1}$ See also Carlsson et al. (2013) for a survey highlighting and summarizing the evolving domain of entrepreneurship research in the past decades.
} 
Moreover, moving from the specific case of KSTE, the paper shows how academic research analyses its focal scientific objectives and phenomena-i.e., knowledge and knowledge spillover mechanisms, entrepreneurs-and the logical links between these phenomena. We are confident that our work will help scholars intending to leverage KSTE in their studies and who face the challenge of navigating novel contributions developed by different authors from different fields and institutions.

The paper is organized as follows. In the next section, we describe the methodology used to identify the basic articles on KSTE included in our literature review. Furthermore, we report the results of our bibliometric analysis in terms of journals where the articles have been published and the results from the backward and forward citation analysis. The main topics within the KSTE debate are then summarized in Sect. 3, in which further research directions are also expressed. Finally, Sect. 4 concludes.

\section{Bibliometric analysis of the KSTE literature}

\subsection{Selection of the articles}

KSTE brings together contemporary theories and thoughts of entrepreneurship with prevailing theories of economic growth. As argued by Acs et al. (2013), it advances the microeconomic foundation of the endogenous growth theory by providing a new framework explaining the unobserved heterogeneity of growth rates between regions and nations. While keeping constant the intrinsic motivation among entrepreneurs, KSTE is concerned with the contextual variables that shape entrepreneurship. Such contextual variables are in particular incumbent firms and research organizations (i.e., knowledge incubators), where knowledge is created and not fully commercialized for purposes of economic gains, and variables shaping that knowledge spill over to other economic agents-namely entrepreneurs. Such knowledge incubators develop new knowledge with potential in the commercial markets but have, for various reasons, opted not to commercialize and exploit that knowledge. This knowledge may spill over to other willing economic agents. The concept of knowledge incubator is unique specifically because of the decision not to enter the market with its new endogenously developed knowledge.
A collection of the relevant articles should encompass academic research dedicated to the analysis of contextual variables, the logic or economic rules and the impact for society. Thus, as an initial access to the literature on KSTE, we included the contributions that are measured by citations the most influential works on $\mathrm{KSTE}^{2}$ : Audretsch (1995), Audretsch and Lehmann (2005) and Acs et al. (2009a). While the book by Audretsch (1995) initiated the theory and coined the term "Knowledge Spillover Theory of Entrepreneur-ship," the study by Audretsch and Lehmann (2005) makes a step in advancing KSTE by proposing the idea that new firm creation is a local endogenous response to knowledge opportunities available at the local level and not exploited by incumbent firms. Expanding the mainstream literature on knowledge spillovers sug-gests that they are geographically bounded in prox-imity to the knowledge source (Jaffe 1989; Audretsch and Feldman 1996 among others), a string of subsequent contributions highlighted the spatial dimension of knowledge spillovers, showing that they decay with distance (see e.g., Audretsch and Keilbach 2007a; Audretsch et al. 2004; Lee et al. 2013). The broadest framework and the biggest step in providing the logical ratio of the KSTE is Acs et al. (2009a), which formalizes the link between the overall stock of knowledge in the economy, the R\&D exploitation by incumbents and the entrepreneurial activity.

Then, we implemented a structured searching process for published or in press articles written in English until the end of 2013 by running three queries on the online database Scopus. ${ }^{3}$ After running queries

\footnotetext{
${ }^{2}$ They totaled 824 citations. 3

http://www.scopus.com. We entered the terms "Knowledge Spillover Theory of Entrepreneurship" (query 1) and "Knowledge Spillover Entrepreneurship" (query 2) in the "Search for" box of Scopus. To avoid being too narrow in our search for target articles, we added one more query (query 3) to include contributions that used synonyms of the term entrepreneurship. These synonyms were generated basing on the keywords of the articles resulting from query 1 and query 2 . Accordingly, query 3 is: "knowledge spillovers" AND ("new ventures" OR "new business" OR "startup" OR "startups" OR "start up" OR "start-up" OR "start-ups" OR "new firm creation" OR "new firm formation"). To circumvent overlapping in the results of the three queries, we included in query 2 and 3 exclusion conditions for the results of the previous queries. Consequently, the articles resulting from query 2 were in addition to articles resulting from query 1 and articles resulting from query 3 were in addition to articles resulting from query 1 and 2 .
} 
Fig. 1 KSTE articles published per year. Note. Two articles that were classified as article in press during the searching process have been published in 2014

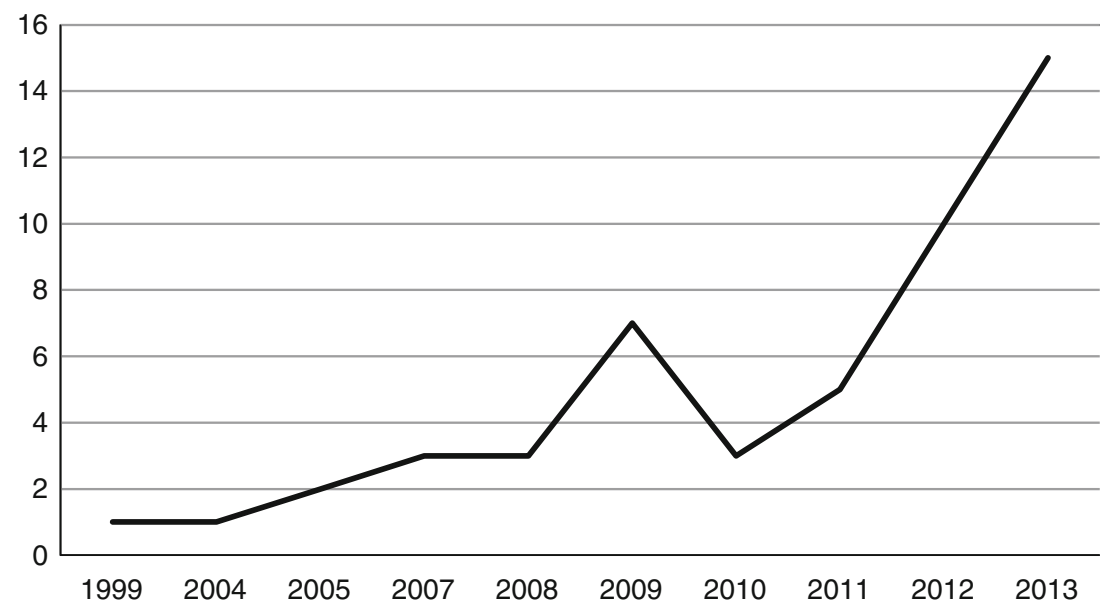

Note. Two articles that were classified as article in press during the searching process have been published in 2014 .
1, 2 and 3, we obtained 170, 77 and 19 articles, respectively, totaling 266 articles. We then dropped all the papers whose abstracts and introduction did not clearly refer to KSTE or to closely related topics (e.g., entrepreneurship, knowledge spillovers, commercialization of research from universities and so on), leading to 52 articles (see table A1 in appendix). The bibliometric analyses, including the analysis of the backward and forward citations as well as the coauthor analysis, are run using the software bibexcel ${ }^{4}$ (Persson et al. 2009).

\subsection{The emergence of the KSTE}

The 52 articles span the period $1999-2013^{5}$ (see Fig. 1). After the first article published by Audretsch and Stephan (1999), there has been a growing attention to KSTE, in particular since 2005. Articles on KSTE have appeared in different academic journals (see Table 1), ranging from entrepreneurship journals to general management and economic journals. ${ }^{6}$ Specifically, nearly half of the articles ( 24 out of 52, 46.1\%) are published in entrepreneurship journals (i.e., Small

\footnotetext{
${ }^{4}$ http://www8.umu.se/inforsk/Bibexcel/.

5 Two articles that were classified as article in press during the searching process have been published in 2014 .

6 Important contributions like Audretsch and Feldman (1996)

or Acs and Audretsch $(1987,1988)$ are excluded, since their main focus is on economics of innovation in general and less on entrepreneurship and knowledge spillovers.
}

Table 1 KSTE articles per academic journal

\begin{tabular}{lll}
\hline Journal & $\begin{array}{l}\text { Number of the } \\
\text { articles }\end{array}$ & $\begin{array}{l}\text { Percentage } \\
(\%)\end{array}$ \\
\hline Small Business Economics & 17 & 33 \\
Research Policy & 6 & 12 \\
10 journals with 2 articles $^{\text {each }}$ & 20 & 38 \\
9 journals with 1 article $_{\text {each }}^{\text {b }}$ & 9 & 17 \\
Total & 52 & 100 \\
\hline
\end{tabular}

${ }^{a}$ Industrial and Corporate Change, Journal of Business Venturing, Annals of Regional Studies, Growth and Change, Papers in Regional Science, Entrepreneurship Theory and Practice, Industry and Innovation, Journal of Evolutionary Economics, Journal of Technology Transfer, Entrepreneurship and Regional Development

b Journal of Management Studies, Oxford Review of Economic Policy, International Journal of Entrepreneurship and Small Business, Academy of Management Journal, Journal of Small Business Management, Journal of Business Research, Journal of Economic Geography, Economic Inquiry, Applied Economic Letters

Business Economics, Entrepreneurship and Regional Development, Entrepreneurship Theory and Practice, Journal of Business Venturing and International Journal of Entrepreneurship and Small Business) and half of them in generalist journals in management and economics (e.g., Research Policy), witnessing the interdisciplinary nature and the wide scope of the KSTE debate. Small Business Economics is still the main outlet of the KSTE debate $(32.7 \%$ of the 


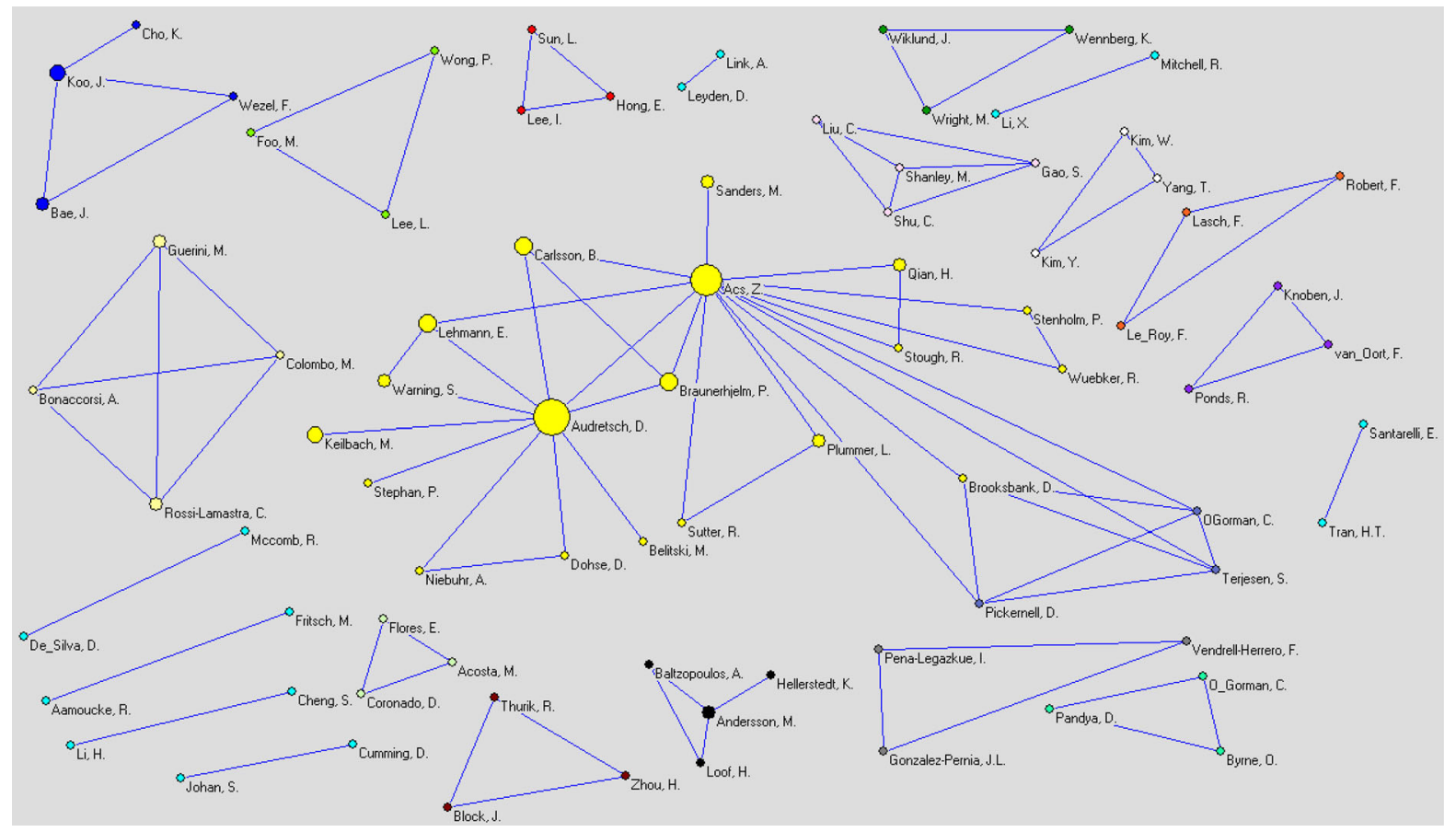

Fig. 2 Coauthorship analysis

articles), followed by Research Policy (11.5\% of the articles).

The 52 articles have been authored by 84 different scholars pointing out that the KSTE community roots on large bases. The scientific community on KSTE is also rapidly growing: from 2010 to 2013 more than 60 new researchers authored papers on KSTE-related subjects. The field is dominated by the initial founders of KSTE, Acs (13 articles) and Audretsch (16 articles). They not only introduced the KSTE, they also influenced the scientific community, as seen in the coauthor analysis (see Fig. 2).

Acs and Audretsch emerge as the central nodes of the community of scholars interested in KSTE. While approximately $30 \%$ of scholars who have published at least one paper on the KSTE have coauthored at least once with Acs and Audretsch, the number of networks of coauthors other than Acs and Audretsch increases pointing out the relevance, openness and emergence of KSTE in the scientific community over time and space. Starting in the US ( 25 authors), KSTE is a main topic in Europe (46 authors) and from other world areas (13 authors).

We perform an analysis of the backward citations of the articles included in this review to organize both internal and external references. ${ }^{7}$ This allows us to identify the most frequently cited references that are then examined to determine the main concepts and ideas invoked by scholars working on KSTE. The 52 articles included in our review count 1,914 nonduplicated references (out of 3,032 references, hereafter: unique references): 27 are internal references (cited in total 136 times) and 1,887 are external ones (cited in total 2,895 times). In total, less than $2 \%$ of all references are internal suggesting that KSTE is by far not a self-referential theory. In other words, KSTE borrows concepts and ideas from outside its own boundaries (e.g., from endogenous growth theory, entrepreneurship and regional economics) and builds on them.

As regards internal unique references, a small set of articles (5 out of $27,18.5 \%$ ) received more than 7 citations from the KSTE articles (see Table 2). This

7 As backward citations (hereafter: references), we intend the citations that the 52 articles made to other scholarly contributions (articles or books). In conducting our analysis, we distinguish between internal references and external references. A reference is internal (external) if one of the articles cites another article included (excluded) in this literature review. 
Table 2 Backward citations, most-cited internal references

\begin{tabular}{|c|c|c|}
\hline Authors (year) & Title of the article & $\begin{array}{l}\text { Number of } \\
\text { citations } \\
\text { from KSTE } \\
\text { articles }\end{array}$ \\
\hline $\begin{array}{r}\text { Acs et al. } \\
(2009 a)\end{array}$ & $\begin{array}{l}\text { The knowledge } \\
\text { spillover theory of } \\
\text { entrepreneurship }\end{array}$ & 27 \\
\hline $\begin{array}{l}\text { Audretsch and } \\
\text { Lehmann } \\
(2005)\end{array}$ & $\begin{array}{l}\text { Does the knowledge } \\
\text { spillover theory of } \\
\text { entrepreneurship hold } \\
\text { for regions? }\end{array}$ & 27 \\
\hline $\begin{array}{l}\text { Audretsch and } \\
\text { Keilbach } \\
(2007 a)\end{array}$ & $\begin{array}{l}\text { The theory of } \\
\text { knowledge spillover } \\
\text { entrepreneurship }\end{array}$ & 15 \\
\hline $\begin{array}{l}\text { Braunerhjelm } \\
\text { et al. (2010) }\end{array}$ & $\begin{array}{l}\text { The missing link: } \\
\text { knowledge diffusion } \\
\text { and entrepreneurship } \\
\text { in endogenous growth }\end{array}$ & 13 \\
\hline $\begin{array}{l}\text { Audretsch et al. } \\
\text { (2005) }\end{array}$ & $\begin{array}{l}\text { University spillovers } \\
\text { and new firm location }\end{array}$ & 7 \\
\hline
\end{tabular}

small set of contributions is cited in total 89 times and accounts for the $65 \%$ of the total internal references ( 89 out of 136). The two most-cited contributions are the ones of Acs et al. (2009a) and Audretsch and Lehmann (2005), counting both 27 citations from KSTE papers. The former work provides a rigorous foundation of theory, in that it models the decision of an individual to become an entrepreneur or not in response to knowledge spillovers and to the presence of the knowledge filter. As aforementioned, the latter paper is one of the initiators of a well-defined stream within KSTE that examines empirically the link between knowledge spillovers and new firm creation at the local level.

\subsection{Components of KSTE}

To identify the basic concepts and components of the KSTE, we devote our attention to external references by focusing on the most-cited articles $^{8}$ (see Table 3) to identify their relevant themes (based on reading and article keywords using the specific tool of Scopus database).

It emerges that KSTE strongly grounds on the literature highlighting knowledge as a crucial input

\footnotetext{
8 The complete list of external references is available from the authors upon request.
}

and resource for firms' economic activities: in particular Jaffe (1989) and the academic knowledge spillovers, Arrow (1962a, b) and the specificity of knowledge, and Griliches (1979) through the knowledge production function. The seminal works of these three authors influenced numerous subsequent studies in the literature on economics of innovation (e.g., Audretsch and Feldman 1996; Anselin et al. 1997; Agarwal et al. 2007) as well as in regional studies (Acs et al. 2002). The other main pillar of KSTE is the literature assessing that entrepreneurship is a fundamental ingredient of economic growth (Audretsch and Thurik 2001; Feldman 2001; Acs and Armington 2006) as well as studies addressing the so-called knowledge paradox. Specifically, countries perform-ing considerable investments in research and in producing new knowledge sometimes experience low rates of economic growth due to low entrepre-neurial activities (Audretsch et al. 2006; Audretsch and Keilbach 2004).

Research in growth theory, namely the seminal work of Solow (1956), Lucas (1988), Romer (1990), Krugman (1991), Aghion and Howitt (1992) or Michelacci (2003), is intensively cited in the KSTE literature. Also, works on entrepreneurial opportunities and knowledge exploitation, in particular Kirzner (1973, 1997), Shane and Venkataraman (2000) and Shane (2001), are cited heavily.

Finally, the literature on agglomeration economies is another important pillar of KSTE. This literature recognizes that the local context matters for new firm creation and growth, in particular since regions differ in their endowment of human and financial capital, the environment fostering entrepreneurial activities, unemployment rates or demographic characteristics. Among the most important contributions as measured by the intensity of citations are Knight (1921), Evans and Leighton (1990), Reynolds (1994), Reynolds et al. (1994, 1995), Armington and Acs (2002), Audretsch and Stephan (1996), Zucker et al. (1998) and Storey (1991). Seminal economic concepts in the literature on agglomeration economies are those of externalities of the type marshallian (Marshall 1920; Feldman and Audretsch 1999; Audretsch and Fritsch 1994) or jacobbian (Jacobs 1969; Lee et al. 2004). While the first externalities are due to economies of scale and scope and learning-by-doing, the latter are due to complementariness. In the first case, clusters should be rather homogenously and large, like biogenetic 
Table 3 Backward citations, most-cited external references

\begin{tabular}{|c|c|c|}
\hline Authors (year) & Title of the article & $\begin{array}{l}\text { Number of citations } \\
\text { from KSTE articles }\end{array}$ \\
\hline Audretsch and Feldman (1996) & $\begin{array}{l}\text { R\&D spillovers and the geography of innovation and } \\
\text { production }\end{array}$ & 26 \\
\hline Audretsch (1995) & Innovation and industry evolution & 21 \\
\hline Jaffe (1989) & Real effects of academic research & 20 \\
\hline Audretsch et al. (2006) & Entrepreneurship and economic growth & 18 \\
\hline Arrow $(1962 a, b)$ & Economic welfare and the allocation of resources for invention & 17 \\
\hline Jacobs (1969) & The economy of cities & 16 \\
\hline Reynolds et al. (1994) & $\begin{array}{l}\text { Cross-national comparisons of the variation in new firm } \\
\text { formation rates }\end{array}$ & 16 \\
\hline Romer (1990) & Endogenous technological change & 14 \\
\hline Anselin et al. (1997) & $\begin{array}{l}\text { Local geographic spillovers between university research and } \\
\text { high technology innovations }\end{array}$ & 15 \\
\hline Armington and Acs (2002) & The determinants of regional variation in new firm formation & 14 \\
\hline Lucas (1988) & On the mechanics of economic development & 13 \\
\hline Audretsch and Stephan (1996) & Company-scientist locational links: the case of biotechnology & 12 \\
\hline Shane and Venkataraman (2000) & The promise of entrepreneurship as a field of research & 11 \\
\hline Lee et al. (2004) & $\begin{array}{l}\text { Creativity and entrepreneurship: a regional analysis of new } \\
\text { firm formation }\end{array}$ & 10 \\
\hline Michelacci (2003) & Low returns in $R \& D$ due to the lack of entrepreneurial skills & 10 \\
\hline Marshall (1920) & Principles of economics & 9 \\
\hline Griliches (1979) & $\begin{array}{l}\text { Issues in assessing the contribution of research and } \\
\text { development to productivity growth }\end{array}$ & 9 \\
\hline Feldman and Audretsch (1999) & $\begin{array}{l}\text { Innovation in cities: science-based diversity, specialization and } \\
\text { localized competition }\end{array}$ & 9 \\
\hline Audretsch and Keilbach (2004) & Entrepreneurship capital and economic performance & 9 \\
\hline Audretsch and Fritsch (1994) & The geography of firm births in Germany & 9 \\
\hline Agarwal et al. (2007) & $\begin{array}{l}\text { The process of creative construction: knowledge spillovers, } \\
\text { entrepreneurship and economic growth }\end{array}$ & 9 \\
\hline Knight (1921) & Risk, uncertainty and profit & 8 \\
\hline Aghion and Howitt (1992) & A model of growth through creative destruction & 8 \\
\hline Zucker et al. (1998) & $\begin{array}{l}\text { Intellectual human capital and the birth of U.S. biotechnology } \\
\text { enterprises }\end{array}$ & 8 \\
\hline Acs et al. (2002) & $\begin{array}{l}\text { Patents and innovation counts as measures of regional } \\
\text { production of new knowledge }\end{array}$ & 8 \\
\hline Storey $(1991)$ & $\begin{array}{l}\text { The birth of new firms-does unemployment matter? A review } \\
\text { of the evidence }\end{array}$ & 8 \\
\hline Reynolds et al. (1995) & $\begin{array}{l}\text { Explaining regional variation in business births and deaths: } \\
\text { U.S. 1976-88 }\end{array}$ & 8 \\
\hline Solow (1956) & A contribution to the theory of economic growth & 7 \\
\hline Kirzner (1997) & $\begin{array}{l}\text { Entrepreneurial discovery and the competitive market process: } \\
\text { An Austrian approach }\end{array}$ & 7 \\
\hline Shane (2001) & Technological opportunities and new firm creation & 7 \\
\hline Audretsch and Thurik (2001) & $\begin{array}{l}\text { What's new about the new economy? Sources of growth in the } \\
\text { managed and entrepreneurial economies }\end{array}$ & 7 \\
\hline Feldman (2001) & $\begin{array}{l}\text { The entrepreneurial event revisited: Firm formation in a } \\
\text { regional context }\end{array}$ & 7 \\
\hline Krugman (1991) & Increasing returns and economic geography & 6 \\
\hline
\end{tabular}


Table 3 continued

\begin{tabular}{llc}
\hline Authors (year) & Title of the article & $\begin{array}{l}\text { Number of citations } \\
\text { from KSTE articles }\end{array}$ \\
\hline Kirzner (1973) & Competition and entrepreneurship & 6 \\
Evans and Leighton (1990) & Small business formation by unemployed and employed & 6 \\
& workers & 6 \\
Acs and Armington (2006) & Entrepreneurship, geography and American economic growth & 6 \\
Reynolds (1994) & Autonomous firm dynamics and economic growth in the & \\
& United States 1986-1990 & \\
\hline
\end{tabular}

clusters, and knowledge spillover effects occur within the same industry. In the second case, clusters should be rather heterogeneous and knowledge spillovers occur across different industries, like in biotechnology.

\subsection{Dissemination and extension of KSTE}

Does the KSTE suffer a single existence or does the knowledge generated by this research spills over the scientific community and fertilizes other research fields and streams? An answer to this question is provided by an analysis of forward citations. For the sake of simplicity, we focused on the 10 most-cited articles within those included in our literature review (see Table 4).

The analysis of forward citations witnesses the vitality of the KSTE debate and the great scholarly interest around it. The 10 most-cited articles in total received 576 citations (with 465 external citations), accounting for slightly less than $80 \%$ of the total number of forward citations received from the 52 articles included in our review (744). Within the 10 most-cited articles, Acs et al. (2009a) is the article that received the highest number of forward citations, followed by Audretsch and Lehmann (2005) and Audretsch et al. (2005). These three articles account for more than $40 \%$ of the total number of citations (320 out of 744).

Evidence of the expansion of KSTE into other fields of research is offered by the spread of citations across different journals. Papers citing the 10 mostcited KSTE articles spread across a large number of academic journals (see Table 5).

However, KSTE is also narrow field of interest, deepening questions related to entrepreneurship, knowledge spillovers and growth. A considerable
Table 4 Forward citations: 10 most-cited KSTE articles

\begin{tabular}{|c|c|c|}
\hline Authors (year) & Title of the article & $\begin{array}{l}\text { Number } \\
\text { of } \\
\text { citations }\end{array}$ \\
\hline $\begin{array}{r}\text { Acs et al. } \\
(2009 a)\end{array}$ & $\begin{array}{l}\text { The knowledge spillover } \\
\text { theory of entrepreneurship }\end{array}$ & 120 \\
\hline $\begin{array}{l}\text { Audretsch and } \\
\text { Lehmann } \\
(2005)\end{array}$ & $\begin{array}{l}\text { Does the knowledge spillover } \\
\text { theory of entrepreneurship } \\
\text { hold for regions? }\end{array}$ & 118 \\
\hline $\begin{array}{l}\text { Audretsch et al. } \\
\text { (2005) }\end{array}$ & $\begin{array}{l}\text { University spillovers and new } \\
\text { firm location }\end{array}$ & 82 \\
\hline $\begin{array}{l}\text { Audretsch and } \\
\text { Keilbach } \\
(2007 a)\end{array}$ & $\begin{array}{l}\text { The theory of knowledge } \\
\text { spillover entrepreneurship }\end{array}$ & 58 \\
\hline $\begin{array}{l}\text { Braunerhjelm } \\
\text { et al. (2010) }\end{array}$ & $\begin{array}{l}\text { The missing link: knowledge } \\
\text { diffusion and } \\
\text { entrepreneurship in } \\
\text { endogenous growth }\end{array}$ & 42 \\
\hline $\begin{array}{l}\text { Audretsch and } \\
\text { Stephan } \\
(1999)\end{array}$ & $\begin{array}{l}\text { Knowledge spillovers in } \\
\text { biotechnology: sources and } \\
\text { incentives }\end{array}$ & 39 \\
\hline $\begin{array}{l}\text { Audretsch } \\
\text { (2007) }\end{array}$ & $\begin{array}{l}\text { Entrepreneurship capital and } \\
\text { economic growth }\end{array}$ & 35 \\
\hline $\begin{array}{l}\text { Audretsch and } \\
\text { Keilbach } \\
(2008)\end{array}$ & $\begin{array}{l}\text { Resolving the knowledge } \\
\text { paradox: knowledge-spillover } \\
\text { entrepreneurship and } \\
\text { economic growth }\end{array}$ & 30 \\
\hline $\begin{array}{l}\text { Carlsson et al. } \\
\text { (2009) }\end{array}$ & $\begin{array}{l}\text { Knowledge creation, } \\
\text { entrepreneurship, and } \\
\text { economic growth: a historical } \\
\text { review }\end{array}$ & 26 \\
\hline $\begin{array}{l}\text { Audretsch et al. } \\
\text { (2004) }\end{array}$ & $\begin{array}{l}\text { University spillovers: does the } \\
\text { kind of science matter? }\end{array}$ & 26 \\
\hline
\end{tabular}

number of papers citing the 10 most-cited articles are from a subset of academic journals related to these questions, like Small Business Economics, Research Policy, Journal of Technology Transfer, Annals of Regional Sciences or Entrepreneurship and Regional Development. 
Table 5 Academic journals publishing articles that cite the 10 most-cited articles on KSTE

\begin{tabular}{ll}
\hline Journal & $\begin{array}{l}\text { Number of } \\
\text { articles }\end{array}$ \\
\hline Small Business Economics & 32 \\
Research Policy & 25 \\
Journal of Technology Transfer & 15 \\
Annals of Regional Science & 10 \\
Entrepreneurship and Regional Development & 10 \\
World Applied Sciences Journal & 10 \\
European Planning Studies & 9 \\
International Journal of Entrepreneurship and & 9 \\
$\quad$ Small Business & \\
Technovation & 8 \\
Entrepreneurship: Theory and Practice & 7 \\
Foundations and Trends in Entrepreneurship & 7 \\
Industry and Innovation & 7 \\
Economic Development Quarterly & 6 \\
Journal of Management Studies & 6 \\
Growth and Change & 5 \\
International Entrepreneurship and Management & 5 \\
Journal & 5 \\
Journal of Business Venturing & 5 \\
Journal of Economic Geography & 5 \\
Science and Public Policy & 5 \\
Other academic journals (134 journals) & 5 \\
\hline & 5 \\
\hline
\end{tabular}

\section{Key questions and topics in the KSTE literature}

As proposed in the introduction, a bona fide field of the KSTE should be both narrow and deep to address the fundamental questions of how and why knowledge spills over by entrepreneurship and generates growth and progress for society. As a second condition, there has to be sufficient commitment and support in the academia and in politics to pursue the research agenda posed by those questions. In this section, we will highlight the main research questions and topics in KSTE to illustrate the narrowness and deepness of KSTE as a theoretical approach. The key questions and topics include the creation of knowledge-based entrepreneurial ventures, the sources and nature of knowledge spillovers and finally the impact of entrepreneurship generated by knowledge spillovers on growth.
3.1 New venture creation and the knowledge filter

The main questions addressed in KSTE are why and how new ventures are created as a response to knowledge spillovers and why does knowledge spill over from incumbent firms and research organizations-i.e., why does the knowledge filter hampers the exploitation of these spillovers by incumbent firms (see Acs et al. 2013 for an overview and discussion).

The key answer is that it is the very nature of knowledge, which is non-excludable and not rival in consumption, and thus not fully appropriable, which creates entrepreneurial opportunities. This idea was early championed by Audretsch and Stephan (1999) analyzing the emergence of new firms in the biotech sector as the endogenous response of biotech scientists. The authors argue that the creation of a new venture is one way to commercialize their knowledge and to appropriate the returns of the knowledge that spills over from universities and R\&D laboratories of incumbent firms. New venture creation as a vehicle and channel for scientists and inventors to translate knowledge spillovers into economic knowledge and growth is since then a major topic in both theoretical and empirical studies in KSTE (Audretsch and Keilbach 2007a; O'Gorman et al. 2008; Braunerhjelm et al. 2010; Acosta et al. 2011; De Silva and McComb 2012; Plummer and Acs (2014); Qian and Acs 2013; Stam 2013 among others).

Related to the translation of knowledge spillovers into economic knowledge is the concept of the knowledge filter. While in the endogenous growth theory (Romer 1990), it is assumed that knowledge spills over automatically, Acs et al. (2004), Audretsch et al. (2006), Braunerhjelm et al. (2010), and Acs et al. (2012a) suggest that instead, the automatic spillover of knowledge from its source is impeded by what they term as the knowledge filter. A valuable attempt of formalizing the concept of knowledge filter is in Acs et al. (2009a). The authors model the link between the overall stock of knowledge in the economy, the R\&D exploitation by incumbents and the entrepreneurial activity. In their theoretical model, knowledge that spills over from its source can potentially be absorbed and commercially exploited by economic agents who are not the knowledge creators. Knowledge exploitation by prospective entrepreneurs through the creation of new ventures depends on their ability to penetrate the knowledge filter, which is the result of all the 
barriers inhibiting the conversion of knowledge produced in R\&D laboratories of incumbent firms and in universities into commercialized knowledge. Several studies, both theoretical (Acs and Sanders 2013; Audretsch 2007) and empirical (Acs et al. 2009b; Qian and Acs 2013; Stuetzer et al. 2014) followed addressing the questions of absorptive capacity by prospective entrepreneurs, the knowledge filter and the vehicle to translate knowledge into growth (Carlsson et al. 2009).

The knowledge filter prevents or at least impedes knowledge from automatically spilling over for innovation and commercialization. Regulations and legal restrictions account for some of the knowledge filter. Consequently, questions addressing the impact of the legal framework and the institutional settings are in the core of the KSTE. Drawing from the institutional theory, Bruton et al. (2010), Veciana and Urbano (2008) or Stenholm et al. (2013) among others empirically analyze how regulative and nor-mative institutions affect entrepreneurial activity triggered by knowledge spillovers. Acs and Sanders (2012) focus on the appropriability regime and theorize how various intellectual property rights regimes alter the incentives of both inventors and innovators. Others focus on the supportive role of the regional innovation system (Kim et al. 2012; Leyden and Link 2013) and the infrastructural endowment (Cumming and Johan 2010) in penetrating the knowledge filter and fostering knowledge spillover entrepreneurship.

\subsection{Nature, type and sources of knowledge}

The next questions that are addressed in the KSTE are about the type, nature and sources of knowledge. In particular, does knowledge from the natural sciences differ for firm creation from knowledge from the social sciences? Does the type of source, i.e., either private incumbent firms or public research organizations matter? How and why does codified knowledge differ from tacit knowledge in affecting new venture creation and venture performance?

The sources of knowledge in the KSTE field are either incumbent firms or research organizations like universities or research institutions, either public or private. While the codified knowledge is often proxied by the number of patents, publications and citations, tacit knowledge is embodied in human capital.

\subsubsection{Publications, patents and human capital}

Plenty of studies focused only on academic research and the relationship of quantity (numbers of patents, articles, citations) on new venture creation with almost mixed results: academic research and codified knowledge is a necessary, but by far no sufficient condition for knowledge spillovers and new venture creation. This shaped the focus toward human capital and tacit knowledge as the mechanisms and channels of knowledge spillovers. One of the first study was Audretsch and Stephan (1999), analyzing the impact of star scientists and their embodied human capital on new firm creation in the biotech industry. Several articles followed, investigating to what extent the relationship between knowledge spillovers and new firm creation depends on spillovers' nature and type. Audretsch and Lehmann (2005) have argued that the relationship of knowledge spillovers and new venture creation is shaped by the type and not only by the nature of knowledge, either as codified or tacit. Their study is one of the first in differentiating between the natural sciences and the social sciences. In analyzing whether and how the number of new high-tech firms located around universities depends on both regional factors and universities' characteristics, the authors document that different spillover mechanisms (e.g., university research activities and university students) and different types of knowledge (knowledge in social science and knowledge in natural science) have different effects. Specifically, research activities in social sciences positively affect new firms' propensity to locate in proximity of universities, while university research activities in natural sciences do not. The opposite happens in case of university students: The number of students in natural sciences positively affects new firm's propensity to locate nearby universities, while the number of students in social sciences does not. Also Acosta et al. (2011) examine the effect of different mechanisms of knowledge spillovers corresponding to diverse university outputs: university graduates, scientific publications and academic patents. They show that the number of university graduates is the most important spillover mechanism in explaining new firm's creation. Wong et al. (2008) argue that different types of knowledge shape entrepreneurship at a different extent and also vary depending on the type of innovative activities undertaken by the incumbents. They show that only 
knowledge created in the development of product innovations generates knowledge spillovers that foster entrepreneurship, while knowledge created while undertaking process innovation does not.

An important stream of literature analyses the academic background of founders on new venture creation and new venture performance (Wennberg et al. 2011; Audretsch et al. 2012) showing that in particular in the first stages of the new venture, academic background but also past industry experience matters for both the creation and performance of new ventures. A rich and promising literature has been emerged in the last years in analyzing a specific channel to generate entrepreneurial ventures which are based on knowledge spillovers: spin-offs (Colombo and Piva 2012; Colombo et al. 2010; O'Gorman et al. 2008; Festel 2013; Karnani 2013; Criaco et al. 2013 for recent studies). While most of these studies do not directly address KSTE as the theoretical workhorse, they are based rather on the same arguments and help to improve our understanding on how knowledge spills over-via human capital and spin-offs. It emerges that scientists are aware of the commercial value of new knowledge when market-related knowledge is embedded in their research context, as well as when they cultivate external contacts with those with market knowledge (O'Gorman et al. 2008 among others).

Like research excellence is not sufficient in new venture creation, neither is it the availability of human capital or spin-offs. Building on notion of absorptive capacity, Qian et al. (2013) and Qian and Acs (2013) recognize new knowledge as a source of entrepreneurial opportunities and human capital as the major source of entrepreneurial absorptive capacity. Such an entrepreneurial absorptive capacity refers to the combination of scientific and business skills needed by perspective entrepreneur to effectively pursuit the knowledge exploitation, but also to the openness and creativity of the local surrounding (Audretsch and Belitski 2013).

\subsubsection{Research institutions and incumbent firms as sources of knowledge}

As aforementioned, universities (or research institutions) and incumbent firms are identified as the main sources of knowledge spillovers. The importance of knowledge spillovers from $R \& D$ investments made by incumbent firms is a crucial assumption made in growth theory (Solow 1956; Romer 1990). But in this literature, the spillovers are assumed to be mainly inter-temporal and thus could be kept within the firm: Investments in R\&D today lead to knowledge that spills over into future periods.

The KSTE doubts that knowledge generated could be kept within the firm as knowledge spills over not only into future periods, but also outside the boundaries of the firm. Patents are published and thus public and so are scientific publications. Key inventors could not be kept and employed involuntarily within the firm. In sum, knowledge, either codified or tacit spills over the boundaries of the firm and leads to new venture creation.

An increasing literature emerged analyzing the characteristics and impacts of incumbent firms on knowledge spillovers and new venture creation. Lasch et al. (2013) focus on the relationship between knowledge spillovers generated by incumbents and new firm creation at the local level confirming positive effects. Santarelli and Tran (2012) obtain similar results with reference to an emerging country, Vietnam. Knoben et al. (2011) discuss the importance of agglomeration effects of incumbent firms for new firm formation. Koo and Cho (2011) show that workers moving from one firm to another are key elements of firm learning process and significantly affect newventure creation. Bae et al. (2011) focus on inter-firm ties by examining the impact of crosscutting ties of incumbents on new firm creation at the local level. They show that new venture creation in a region is positively related to the number of crosscutting ties established by incumbents in that region. Andersson et al. (2012) consider R\&D strategies of incumbent firms and investigate whether and how they affect the number and the quality of the new ventures founded by their ex-employee in knowledge intensive business services and argue that new ventures with founders previously employed in persistent $R \& D$ investment firms outperform, as measured by firm survival.

The impact of universities and academic research institutions on new-firm creation and thus the link between research output and new venture creation and performance is a main topic in the academia. Results are summarized in books (e.g., Audretsch et al. 2006), different Special Issues and edited Volumes. Common sense is that academic research is important and necessary, but by far not sufficient for new venture 
creation. Most of the literature rationalizes ex post the importance of outstanding research institutions (e.g., Saxenian 1994) on new venture creation and firm performance. Within this strand of literature, the role of technology transfer offices (TTO) to promote the commercialization process of academic research is intensively discussed and analyzed, finding mixed evidence (see Bozeman et al. 2013; Breznitz and Feldman 2012; Hülsbeck et al. 2013). Fritsch and Aamoucke (2013) document that both the presence and the size of public academic institutions have a significant effect on the new firm creation in Germany, but only as far as innovative industries are concerned. More comprehensively, Bonaccorsi et al. (2013) explore how university knowledge fosters entrepreneurship and show that university specialization in applied sciences and engineering has a positive effect on local entrepreneurship in service industries and specifically in the knowledge-intensive business services.

A related question deals with proximity: does geographic distance to the source of knowledge matter for new venture creation and performance? A rich empirical literature emerged analyzing when and how distance matters (see Audretsch et al. 2006). For instance, Audretsch et al. (2004) found that young high-tech start-ups locate close to highly productive universities with a high number of students in both natural and social science. De Silva and McComb (2012) demonstrate that proximity to universities positively affects entrepreneurship rates in Texas, but the new firm created in proximity of universities does not benefit from university knowledge spillovers after the start-up phase. As to incumbent firms, knowledge spillovers on new firm creation tend to be geographically bounded as well and decay rapidly across geographic space (Lee et al. 2013).

However, while the overwhelming part of the empirical studies confirms the importance of close proximity toward the next source of knowledge, further research should focus on differences across countries (Urbano and Alvarez 2014). Expanding on these results, a logical question arises whether the spatial concentration of both the two sources of knowledge generates synergistic gains for new creation. In a recent contribution, Guerini and RossiLamastra (2014) study the interaction between knowledge generated by universities and knowledge generated by incumbent firms in fostering new firm creation at the local level. They find that university knowledge exerts an effect just in areas where industry knowledge is low, suggesting that the two types of knowledge seem to be substitutes as to new firm creation.

\subsection{Regional endowment and firm competition}

An important question addressed in KSTE is the impact of regional endowment on new venture creation and performance. Bae and Koo (2009) highlight the importance of knowledge relatedness and diversity. Knowledge relatedness refers to the extent to which knowledge bases in a region are complementary among each another, so that the value of pooling different knowledge sources is greater than the total value of the individual sources. Conversely, knowl-edge diversity refers to the extent to which knowledge in a region is dissimilar (either functionally or technically). Both knowledge relatedness and diver-sity positively impacts on new firm creation, but the effects of diversity is the strongest. The leading importance of knowledge diversity is acknowledged by Bishop (2012) who bases on insights from the broader literature on the effects of diversity.

As regards heterogeneity across contexts, regional diversity on the exploitation of knowledge spillovers through entrepreneurship is analyzed empirically. Audretsch et al. (2010) were among the first to deal with this issue in the KSTE framework. They distinguish between diversity at the industry (sectoral diversity) and individual level (that the authors label as cultural diversity) and show that sectoral diversity negatively influences entrepreneurship at local level, while cultural diversity, as measured by a Theil index of each ethnic group in the region's total labor force, facilitates the exploitation of knowledge spillovers from incumbent firms. Cheng and Li (2012) confirm these findings for the USA and show that either cultural or racial diversity has a positive effect on new venture creation in given industries. Furthermore, regional diversity positively affects new firm creation in neighboring counties. Plummer and Acs (2014) show that knowledge exploitation for new firm creation strongly depends on localized competition, which refers to "struggle for ideas and knowledge embodied in economic agents" (Plummer and Acs 2014, p. 6). Incumbents and new ventures compete for the same scarce resources within a given region. Measuring new firm creation in USA at the county 
level, the authors find that knowledge availability, as measured by the number of patents in a county, has a positive impact of local entrepreneurship, while the effect of localized competition is negative. Localized competition also negatively moderates the positive relationship between knowledge availability and new firm creation. Also Andersson and Hellerstedt (2009) show that new venture creation at the local level in knowledge intensive business services is shaped by the market potential of the local area. They highlight that new venture creation is positively affected by the regional knowledge stock and by the presence of incumbent firms in knowledge-based industries.

\subsection{Linking KSTE to growth}

A major research question in KSTE addresses impacts for society, in particular economic growth (Audretsch 2007, 2009, 2012; Audretsch et al. 2006). Several papers included in this review explicitly consider the relation between entrepreneurship enabled by knowledge spillovers and economic growth. That investment in knowledge not automatically leads to an increase in economic growth, as proposed by endogenous growth theory, is known as the Swedish Paradox or puzzle. It is the knowledge filter that left knowledge uncommercialized by incumbent firms. Audretsch and Keilbach (2008) show that entrepreneurial activities penetrate the knowledge filter and demonstrate that regional economic growth is positively influenced by the entrepreneurial activity. Stam (2013) finds that the knowledge stock at the national level is positively correlated with corporate entrepreneurship. He suggests that when studying the relation between entrepreneurship and innovation, one should consider not only independent entrepreneurship but also corporate entrepreneurship. Gonzalez-Pernia et al. (2012), coherently with what has been found by Audretsch and Keilbach (2007b), show a positive relationship between new knowledge generation and growth when controlled for entrepreneurial activities. New knowledge generation has the effect of creating new ideas, while entrepreneurial activity is the vehicle and channel of commercialization of new ideas.

Similar findings for a broader databases with multiple regions and countries are provided by Braunerhjelm et al. (2010). Their results considerably confirm the propositions made in the KSTE by linking entrepreneurship to new knowledge generation and economic growth at a national level. They also show that entrepreneurship policies matter to promote growth. Acs et al. (2012a) reinforce this view using a panel of entrepreneurship data from 18 countries. Their results show that, in addition to measures of R\&D and human capital, entrepreneurial activity serves to promote economic growth.

KSTE also offers a framework in analyzing growth effects in regions and economies with poor economic growth. The study of Acs et al. (2009b) is based on data from Ohio. Ohio is affected by knowledge created locally, but is faced with a declining industry. The authors show that-also in a declining economy - the contribution of local knowledge to economic growth depends on the propensity of a region to create new firms. The same holds for other regions with low growth rates in the UK and Ireland (Acs et al. 2012).

\subsection{Expanding the boundaries of the KSTE and future research}

Finally, we will point out the research questions expanding the boundaries of KSTE and indicate some questions dedicated to future research. Within the context of the generation and exploitation of knowledge, inter-organizational alliances, networks and collabora-tions are discussed. Hayter (2013) extends the KSTE building on the network approach to entrepreneurship and provides a literature review on the role of networks in encouraging and supporting knowledge-based entrepre-neurship, by considering different disciplines. Shu et al.(2013) build on the two conceptual pillars of KSTE, knowledge spillovers and the knowledge filter, to investigate the performance of firms engaged in alli-ances. They show that knowledge spillovers positively affect alliance performance, but not for equity joint ventures and individual firm performance. The moder-ating role of entrepreneurial activities is expressed by a firm's entrepreneurial orientation (corporate entrepre-neurship) that leads to a higher generation of knowledge spillovers. One future direction for research related to the KSTE is thus on the impact of corporate entrepreneur-ship as an internal, central, substitute for incumbents opposed to external, decentralise, entrepreneurial activ-ities and new venture creations.

Recent contributions, like Block et al. (2013) link the KSTE to innovation economics and analyze the effect of entrepreneurship on the transformation of knowledge into innovation. They discriminate 
between new-to-the-market and new-to-the-firm innovation to disentangle between and demonstrate that entrepreneurship positively moderates the relation between the stock of knowledge that a country holds and new-to-the-market innovation. These studies confirm findings from KSTE in that entrepreneurs are not necessarily the creators of knowledge, but are the agents - the channel-transforming knowledge into marketable products into new markets. A prom-ising research agenda is thus the impact of new venture creation for creating new markets and new opportunities in a Schumpeterian sense.

Like knowledge is left uncommercialized by incumbent firms, growth opportunities are left uncommercialized by entrepreneurial ventures. New ventures, although successful by transforming knowledge and ideas into marketable products, often suffer in their growth opportunities by a lack of capital and other critical resources. This gives an incentive to incumbents to attract new business and new opportunities by taking these firms over. This leads to matching mechanisms with a win-win situation for both, the incumbent as the acquirer and the new venture as the target firm. Several empirical papers are analyzing this matching process, proposed by Lichtenberg and Siegel (1989) like Bonardo et al. (2010), Lehmann et al. (2012) and thus complete the process from knowledge generation by incumbents to knowledge exploitation by new venture creation toward reaching the products to maturity by large and established firms. Future research could shed light on this division of labor between incumbent firms and new ventures in exploiting knowledge spillovers and at least transform the ideas into marketable products.

Another topic is the importance of the KSTE in explaining growth opportunities in emerging markets. $\mathrm{Li}$ and Mitchell (2009) investigate the pace and the stability of firm's innovation in a transitional economy, like China. Future research could shed more light on the importance of new venture creation for growth in the lack of large incumbent firms and local research institutes and universities as the main sources of knowledge spillovers.

\section{Concluding remarks}

Within the evolving domain of entrepreneurship research, KSTE has been established as a fruitful and promising approach expanding the endogenous growth theory by linking entrepreneurship to knowledge spillovers. This approach suggests that there may be alternative perspectives on knowledge spillovers within large and established firms, shedding a different light, not just on why some people choose to become entrepreneurs while others do not, but also on how and why entrepreneurship is a critical issue in regard to improving economic performance. By commercializing independently the ideas that evolved from an incumbent organization via the creation of a new firm, the entrepreneurs not only serve as a conduit for the spillovers of knowledge, but also for the ensuing innovative activity and enhanced economic performance.

This paper took the stock of what has been said KSTE, by both mapping the community of scholars debating on this strand of literature and by synthesizing the major research streams that are emerged with this theoretical perspective. We are confident that our work will be of great help for scholars intending to leverage KSTE in their research in that it summarizes what are the main conversations within this theoretical perspective and who are the researchers animating it. As to the future research directions, we believe that it would be of great interest to investigate how the characteristics of local areas influence the process of transformation of knowledge spillovers in new businesses by comparing different institutional settings and national systems of entrepreneurship. Enhancing our understanding on the extent to which national and local characteristics moderate the conversion of knowledge spillovers into the creation of entrepreneurial ventures would have significant policy implications on the local and country level.

\section{References}

Acosta, M., Coronado, D., \& Flores, E. (2011). University spillovers and new business location in high-technology sectors: Spanish evidence. Small Business Economics, 36(3), 365-376.

Acs, Z. J., Anselin, L., \& Varga, A. (2002). Patents and innovation counts as measures of regional production of new knowledge. Research Policy, 31(7), 1069-1085.

Acs, Z. J., \& Armington, C. (2006). Entrepreneurship, geography and American economic growth. Cambridge: Cambridge University Press.

Acs, Z. J., \& Audretsch, D. B. (1987). Innovation, market structure, and firm size. Review of Economics and Statistics, 69(4), 567-574. 
Acs, Z. J., \& Audretsch, D. B. (1988). Innovation in large and small firms: An empirical analysis. American Economic Review, 78(4), 678-690.

Acs, Z. J., Audretsch, D. B., Braunerhjelm, P., \& Carlsson, B. (2004). The missing link: The knowledge filter and endogenousgrowth (discussion paper). Stockholm: Center for Business and Policy Studies.

Acs, Z. J., Audretsch, D. B., Braunerhjelm, P., \& Carlsson, B. (2012a). Growth and entrepreneurship. Small Business Economics, 39(2), 289-300.

Acs, Z. J., Audretsch, D. B., \& Feldman, M. P. (1994). R\&D spillovers and recipient firm size. Review of Economics and Statistics, 76(2), 336-340.

Acs, Z. J., Audretsch, D. B., \& Lehmann, E. E. (2013). The knowledge spillover theory of entrepreneurship. Small Business Economics, 41(4), 757-774.

Acs, Z. J., Braunerhjelm, P., Audretsch, D. B., \& Carlsson, B. (2009a). The knowledge spillover theory of entrepreneurship. Small Business Economics, 32(1), 15-30.

Acs, Z. J., Brooksbank, D. J., O'Gorman, C., Pickernell, D., \& Terjesen, S. (2012b). The knowledge spillover theory of entrepreneurship: An application to foreign direct investment. International Journal of Entrepreneurship and Small Business, 15(2), 237-261.

Acs, Z. J., Plummer, L. A., \& Sutter, R. (2009b). Penetrating the knowledge filter in "rust belt" Economies. Annals of Regional Studies, 43(4), 989-1012.

Acs, Z. J., \& Sanders, M. (2012). Patents, knowledge spillovers, and entrepreneurship. Small Business Economics, 39(4), 801-817.

Acs, Z. J., \& Sanders, M. (2013). Knowledge spillover entrepreneurship in an endogenous growth model. Small Business Economics, 41(4), 775-795.

Agarwal, R., Audretsch, D. B., \& Sarkar, M. B. (2007). The process of creative construction: Knowledge spillovers, entrepreneurship and economic growth. Strategic Entrepreneurship Journal, 1(3-4), 236-286.

Agarwal, R., Echambadi, R., Franco, A. M., \& Sarkar, M. B. (2004). Knowledge transfer through inheritance: Spin-out generation, development, and survival. Academy of Management Journal, 47(4), 501-511.

Aghion, P., \& Howitt, P. (1992). A model of growth through creative destruction. Econometrica, 60(2), 323-351.

Andersson, M., Baltzopoulos, A., \& Lööf, H. (2012). R\&D strategies and entrepreneurial spawning. Research Policy, 41(1), 54-68.

Andersson, M., \& Hellerstedt, K. (2009). Location attributes and start-ups in knowledge-intensive business services. Industry and Innovation, 16(1), 103-121.

Anselin, L., Varga, A., \& Acs, Z. J. (1997). Local geographic spillovers between university research and high technology innovations. Journal of Urban Economics, 42(3), 422-448.

Armington, C., \& Acs, Z. J. (2002). The determinants of regional variation in new firm formation. Regional Studies, 36(1), 33-45.

Arrow, K. (1962a). Economic welfare and the allocation of resources for invention. In R. Nelson (Ed.), The rate and direction of inventive activity (pp.609-626). Princeton, NJ: Princeton University Press.

Arrow, K. J. (1962b). The economic implications of learning by doing. Review of Economic Studies, 29(3), 155-173.
Audretsch, D. B. (1995). Innovation and industry evolution. Cambridge, MA: MIT Press.

Audretsch, D. B. (2007). Entrepreneurship capital and economic growth. Oxford Review of Economic Policy, 23(1), 63-78.

Audretsch, D. B. (2009). The entrepreneurial society. The Journal of Technology Transfer, 34(3), 245-254.

Audretsch, D. B., \& Belitski, M. (2013). The missing pillar: the creativity theory of knowledge spillover entrepreneurship. Small Business Economics, 41(4), 819-836.

Audretsch, D. B., Dohse, D., \& Niebuhr, A. (2010). Cultural diversity and entrepreneurship: A regional analysis for Germany. The Annals of Regional Science, 45(1), 55-85.

Audretsch, D. B., \& Feldman, M. P. (1996). Innovation in cities: Science-based diversity, specialization and localized competition. European Economic Review, 43(2), 409-429.

Audretsch, D. B., \& Fritsch, M. (1994). The geography of firm births in Germany. Regional Studies, 28(4), 359-365.

Audretsch, D. B., Hülsbeck, M., \& Lehmann, E. E. (2012). Regional competitiveness, university spillovers and entrepreneurial activity. Small Business Economics, 39(3), 587-601.

Audretsch, D. B., \& Keilbach, M. (2004). Entrepreneurship capital and economic performance. Regional Studies, 38(8), 949-959.

Audretsch, D. B., \& Keilbach, M. (2007a). The theory of knowledge spillover entrepreneurship. Journal of Management Studies, 44(7), 1242-1254.

Audretsch, D. B., \& Keilbach, M. (2007b). The localisation of entrepreneurship capital: Evidence from Germany. Papers in Regional Science, 86(3), 351-365.

Audretsch, D. B., \& Keilbach, M. (2008). Resolving the knowledge paradox: Knowledge-spillover entrepreneurship and economic growth. Research Policy, 37(10), 1697-1705.

Audretsch, D. B., Keilbach, M., \& Lehmann, E. E. (2006). Entrepreneurship and economic growth. Oxford: Oxford University Press.

Audretsch, D. B., \& Lehmann, E. E. (2005). Does the knowledge spillover theory of entrepreneurship hold for regions? Research Policy, 34(8), 1191-1202.

Audretsch, D. B., Lehmann, E. E., \& Warning, S. (2004). University spillovers: Does the kind of science matter? Industry and Innovation, 11(3), 193-205.

Audretsch, D. B., Lehmann, E. E., \& Warning, S. (2005). University spillovers and new firm location. Research Policy, 34(7), 1113-1122.

Audretsch, D. B., \& Link, A. (2012). Valuing an entrepreneurial enterprise. Small Business Economics, 38(2), 139-145.

Audretsch, D. B., \& Stephan, P. E. (1996). Company-scientist locational links: The case of biotechnology. American Economic Review, 86(3), 641-652.

Audretsch, D. B., \& Stephan, P. E. (1999). Knowledge spillovers in biotechnology: Sources and incentives. Journal of Evolutionary Economics, 9(1), 97-107.

Audretsch, D. B., \& Thurik, A. R. (2001). What's new about the new economy? Sources of growth in the managed and entrepreneurial economies. Industrial and Corporate Change, 10(1), 267-315.

Bae, J., \& Koo, J. (2009). The nature of local knowledge and new firm formation. Industrial and Corporate Change, 18(3), 473-496. 
Bae, J., Wezel, F. C., \& Koo, J. (2011). Cross-cutting ties, organizational density, and new firm formation in the U.S. biotech industry, 1994-98. Academy of Management Journal, 54(2), 295-311.

Bishop, P. (2012). Knowledge, diversity and entrepreneurship: A spatial analysis of new firm formation in Great Britain. Entrepreneurship and Regional Development, 24(7-8), 641-660.

Block, J. H., Thurik, R., \& Zhou, H. (2013). What turns knowledge into innovative products? The role of entrepreneurship and knowledge spillovers. Journal of Evolutionary Economics, 23(4), 693-718.

Bonaccorsi, A., Colombo, M. G., Guerini, M., \& Rossi-Lamastra, C. (2013). University specialization and new firm creation across industries. Small Business Economics, 41(4), 837-863.

Bonardo, D., Paleari, S., \& Vismara, S. (2010). The M\&A dynamics of European science-based entrepreneurial firms. The Journal of Technology Transfer, 35(1), 141-180.

Bozeman, B., Fay, D., \& Slade, C. P. (2013). Research collaboration in universities and academic entrepreneurship: The-state-of-the-art. The Journal of Technology Transfer, 38(1), 1-67.

Braunerhjelm, P., Acs, Z. J., Audretsch, D. B., \& Carlsson, B. (2010). The missing link: Knowledge diffusion and entrepreneurship in endogenous growth. Small Business Economics, 34(2), 105-125.

Breznitz, S. M., \& Feldman, M. P. (2012). The engaged university. The Journal of Technology Transfer, 37(2), 139-157.

Bruton, G. D., Ahlstrom, D., \& Li, H.-L. (2010). Institutional theory and entrepreneurship: Where are we now and where do we need to move in the future? Entrepreneurship Theory and Practice, 34(3), 421-440.

Carlsson, B., Acs, Z. J., Audretsch, D. B., \& Braunerhjelm, P. (2009). Knowledge creation, entrepreneurship, and economic growth: A historical review. Industrial and Corporate Change, 18(6), 1193-1229.

Carlsson, B., Braunerjhelm, P., McKelvey, M., Olofsson, C., Persson, L., \& Ylinenpää, H. (2013). The evolving domain of entrepreneurship research. Small Business Economics, 41, 913-930.

Carlsson, B., \& Fridh, A. C. (2002). Technology transfer in United States universities. Journal of Evolutionary Economics, 12(1-2), 199-232.

Cheng, S., \& Li, H. (2012). New firm formation facing cultural and racial diversity. Papers in Regional Science, 91(4), 759-774.

Colombo, M. G., Mustar, P., \& Wright, M. (2010). Dynamics of science-based entrepreneurship. Journal of Technology Transfer, 35(1), 1-15.

Colombo, M. G., \& Piva, E. (2012). Firms' genetic characteristics and competence-enlarging strategies: A comparison of academic and non-academic high-tech start-ups. Research Policy, 41(1), 79-92.

Criaco, G., Minola, T., Migliorini, P., \& Serarols-Tarrés, C. (2013). To have and have not: Founders' human capital and university start-up survival. The Journal of technology Transfer, doi:10.1007/s10961-013-9312-0.

Cumming, D., \& Johan, S. (2010). The differential impact of the internet on spurring regional entrepreneurship. Entrepreneurship Theory and Practice, 34(5), 857-883.
De Silva, D. G., \& McComb, R. (2012). Research universities and regional high-tech firm start-up and exit. Economic Inquiry, 50(1), 112-130.

Evans, D. S., \& Leighton, L. S. (1990). Small business formation by unemployed and employed workers. Small Business Economics, 2(4), 319-330.

Feldman, M. P. (2001). The entrepreneurial event revisited: Firm formation in a regional context. Industrial and Corporate Change, 10(4), 861-891.

Feldman, M. P., \& Audretsch, D. B. (1999). Innovation in cities: Science-based diversity, specialization and localized competition. European Economic Review, 43(2), 409-429.

Festel, G. (2013). Academic spin-offs, corporate spin-outs and company internal start-ups as technology transfer approach. The Journal of Technology Transfer, 38(4), 454-470.

Florida, R. L. (2002). The rise of the creative class. New York: Basic Books.

Florida, R. L. (2004). Cities and the creative class. New York: Routledge.

Fritsch, M., \& Aamoucke, R. (2013). Regional public research, higher education, and innovative start-ups: An empirical investigation. Small Business Economics, 41(4), 865-885.

Gonzalez-Pernia, J. L., Pena-Legazkue, I., \& Vendrell-Herrero, F. (2012). Innovation, entrepreneurial activity and competitiveness at a sub-national level. Small Business Economics, 39(3), 561-574.

Griliches, Z. (1979). Issues in assessing the contribution of research and development to productivity growth. Bell Journal of Economics, 10(1), 92-116.

Guerini, M., \& Rossi-Lamastra, C. (2014). How university and industry knowledge interact to determine local entrepreneurship. Applied Economic Letters, 21(8), 513-516.

Guerrero, M., \& Urbano, D. (2014). Academics' start-up intentions and knowledge filters: an individual perspective of the knowledge spillover theory of entrepreneurship. Small Business Economics, . doi:10.1007/ s11187-013-9526-4.

Hayter, C. S. (2013). Conceptualizing knowledge-based entrepreneurship networks: Perspectives from the literature. Small Business Economics, 41(4), 899-911.

Hülsbeck, M., Lehmann, E. E., \& Starnecker, A. (2013). Performance of technology transfer offices in Germany. Journal of Technology Transfer, 38(3), 199-215.

Jacobs, J. (1969). The economy of cities. New York: Random House.

Jaffe, A. B. (1989). Real effects of academic research. American Economic Review, 79(5), 957-970.

Jaffe, A. B., Trajtenberg, M., \& Henderson, R. (1993). Geographic localization of knowledge spillover as evidenced by patent citations. Quarterly Journal of Economics, 63(3), 577-598.

Karnani, F. (2013). The university's unknown knowledge: Tacit knowledge, technology transfer and university spin-offs findings from an empirical study based on the theory of knowledge. The Journal of Technology Transfer, 38(3), 235-250.

Kim, Y., Kim, W., \& Yang, T. (2012). The effect of the triple helix system and habitat on regional entrepreneurship: Empirical evidence from the U.S. Research Policy, 41(1), 154-166. 
Kirzner, I. M. (1973). Competition and entrepreneurship. Cichago: University of Chicago Press.

Kirzner, I. M. (1997). Entrepreneurial discovery and the competitive market process: An Austrian approach. Journal of Economic Literature, 35(1), 60-85.

Knight, F. H. (1921). Risk, uncertainty and profit. Boston: Houghton Mifflin Company.

Knoben, J., Ponds, R., \& van Oort, F. (2011). Employment from new firm formation in the Netherlands: Agglomeration economies and the knowledge spillover theory of entrepreneurship. Entrepreneurship and Regional Development, 23(3-4), 135-157.

Koo, J., \& Cho, K.-R. (2011). New firm formation and industry clusters: A case of the drugs industry in the U.S. Growth and Change, 42(2), 179-199.

Krugman, P. (1991). Increasing returns and economic geography. Journal of Political Economy, 99(3), 483-499.

Lasch, F., Robert, F., \& Le Roy, F. (2013). Regional determinants of ICT new firm formation. Small Business Economics, 40(3), 671-686.

Lee, S. Y., Florida, R. L., \& Acs, Z. J. (2004). Creativity and entrepreneurship: A regional analysis of new firm formation. Regional Studies, 38(8), 879-891.

Lee, I. H., Hong, E., \& Sun, L. (2013). Regional knowledge production and entrepreneurial firm creation: Spatial dynamic analyses. Journal of Business Research, 66(10), 2106-2115.

Lehmann, E. E., Braun, T. V., \& Krispin, S. (2012). Entrepreneurial human capital, complementary assets, and takeover probability. The Journal of Technology Transfer, 37(5), 589-608.

Leyden, D. P., \& Link, A. (2013). Knowledge spillovers, collective entrepreneurship, and economic growth: The role of universities. Small Business Economics, 41(4), 797-817.

Li, X., \& Mitchell, R. K. (2009). The pace and stability of small enterprise innovation in highly dynamic economies: A China-based template. Journal of Small Business Management, 47(3), 370-397.

Lichtenberg, F. R., \& Siegel, D. S. (1989). The effect of control changes on the productivity of U.S. manufacturing plants. Journal of Applied Corporate Finance, 2(2), 60-67.

Lucas, R. (1988). On the mechanics of economic development. Journal of Monetary Economics, 22(1), 3-42.

Marshall, A. (1920). Principles of economics. London: Macmillan.

Michelacci, C. (2003). Low returns in R\&D due to the lack of entrepreneurial skills. Economic Journal, 113(484), 207-225.

O'Gorman, C., Byrne, C., \& Pandya, O. D. (2008). How scientists commercialise new knowledge via entrepreneurship. The Journal of Technology Transfer, 33(1), 23-43.

Persson, O., Danell, R., \& Schneider, J. W. (2009). How to use Bibexcel for various types of bibliometric analysis. In Celebrating Scholarly Communication Studies: A Festschrift for Olle Persson at his 60th Birthday, international society for scientometrics and informetrics (pp. 9-24). Umeå and Sydney: Aalborg, Copenhagen.

Plummer, L. A., \& Acs, Z. J. (2014). Localized competition in the knowledge spillover theory of entrepreneurship. Journal of Business Venturing, 29(1), 121-136.

Qian, H., \& Acs, Z. J. (2013). An absorptive capacity theory of knowledge spillover entrepreneurship. Small Business Economics, 40(2), 185-197.
Qian, H., Acs, Z. J., \& Stought, R. R. (2013). Regional systems of entrepreneurship: the nexus of human capital, knowledge and new firm formation. Journal of Economic Geography, 13(4), 559-587.

Raasch, C., Lee, V., Spaeth, S., \& Herstatt, C. (2013). The rise and fall of interdisciplinary research: The case of open source innovation. Research Policy, 42(5), 1138-1151.

Reynolds, P. D. (1994). Autonomous firm dynamics and economic growth in the United States, 1986-1990. Regional Studies, 28(4), 429-442.

Reynolds, P. D., Miller, B., \& Maki, W. R. (1995). Explaining regional variation in business births and deaths: U.S. 1976-88. Small Business Economics, 7(5), 389-407.

Reynolds, P., Storey, D., \& Westhead, P. (1994). Cross-national comparisons of the variation in new firm formation rates. Regional Studies, 28(4), 443-456.

Romer, P. (1986). Increasing returns and long run growth. Journal of Political Economy, 94(5), 1002-1037.

Romer, P. (1990). Endogenous technological change. Journal of Political Economy, 98(5), S71-S102.

Santarelli, E., \& Tran, H. T. (2012). Growth of incumbent firms and entrepreneurship in Vietnam. Growth and Change, 43(4), 638-666.

Saxenian, A. (1994). Regional advantage: Culture and competition in Silicon Valley and Route 128. Cambridge: Harvard University Press.

Schumpeter, J. A. (1934). Theorie der Wirtschaftlichen Entwicklung ("The theory of economic development') (trans: Opie, D.). Leipzig: Dunker \& Humblot. Cambridge: Harvard University Press.

Schumpeter, J. A. (1942). Capitalism, socialism and democracy. New York: Harper and Row.

Shane, S. (2000). Prior knowledge and the discovery of entrepreneurial opportunities. Organization Science, 11(4), 448-469.

Shane, S. (2001). Technological opportunities and new firm creation. Management Science, 47(2), 205-220.

Shane, S., \& Venkataraman, S. (2000). The promise of entrepreneurship as a field of research. Academy of Management Review, 25(1), 217-226.

Shu, C., Liu, C., Gao, S., \& Shanley, M. (2013). The knowledge spillover theory of entrepreneurship in alliances. Entrepreneurship Theory and Practice,.doi:10.1111/etap.12024.

Solow, R. M. (1956). A contribution to the theory of economic growth. Quarterly Journal of Economics, 70(1), 65-94.

Stam, E. (2013). Knowledge and entrepreneurial employees: A country-level analysis. Small Business Economics, 41(4), 887-898.

Stenholm, P., Acs, Z. J., \& Wuebker, R. (2013). Exploring country-level institutional arrangements on the rate and type of entrepreneurial activity. Journal of Business Venturing, 28(1), 176-193.

Storey, D. J. (1991). The birth of new firms-does unemployment matter? A review of the evidence. Small Business Economics, 3(3), 167-178.

Stuetzer, M., Obschonka, M., Sternberg, R., \& Cantner, U. (2014). Regional characteristics, opportunity perception and entrepreneurial activity. Small Business Economics, 42(2), 221-244.

Urbano, D., \& Alvarez, D. (2014). Institutional dimensions and entrepreneurial activity: An international study. Small Business Economics, 42(4), 703-716. 
Veciana, J., \& Urbano, D. (2008). The institutional approach to entrepreneurship research. Introduction. International Entrepreneurship and Management Journal, 4(4), 365-379.

Venkataraman, S. (1997). The distinctive domain of entrepreneurship research: An editor's perspective. Advances in entrepreneurship, firm emergence, and growth, 3, 119-138.

Wennberg, K., Wiklundc, J., \& Wright, M. (2011). The effectiveness of university knowledge spillovers: Performance differences between university spinoffs and corporate spinoffs. Research Policy, 40(8), 1128-1143.

Wong, P. K., Lee, L., \& Der Foo, M. (2008). Occupational choice: The influence of product vs. process innovation. Small Business Economics, 30(3), 267-281.

Zucker, L. G., Darby, M. R., \& Brewer, M. B. (1998). Intellectual human capital and the birth of U.S. biotechnology enterprises. American Economic Review, 88(1), 290-306. 